\begin{tabular}{|l|c|c|c|c|}
\hline ACTA CARSOLOGICA & $31 / 3$ & 6 & $99-114$ & LJUBLJANA 2002 \\
\hline
\end{tabular}

COBISS: 1.08

\title{
THE MONTI BERICI: A PECULIAR TYPE OF KARST IN THE SOUTHERN ALPS
}

\author{
HRIBOVJE MONTI BERICI: \\ SVOJSKI TIP KRASA V JUŽNIH ALPAH
}

UGO SAURO $^{1}$

${ }^{1}$ Dipartimento di Geografia - Università degli Studi di Padova, via del Santo 26 - 35123 PADOVA, ITALY e-mail: ugo.sauro@unipd.it

Prejeto / received: 21. 9. 2002 


\section{Ugo Sauro: Hribovje Monti Berici: svojski tip krasa v Južnih Alpah}

Hribovje Monti Berici predstavljajo najjužnejšo kraško morfološko enoto Južnih Alp in obenem svojski tip krasa. Analiza njihove topografije, ugotavljanje morfostratigrafskih ostankov uravnanih površij in različnih rečnih oblik, zaznavanje nekaterih elementov, pomembnih za kronologijo, predstavljenih v tem sestavku, so dovolj, da si je mogoče zamisliti predhodni model geomorfološkega razvoja te gorske skupine. Vodilni morfogenetski elementi so fluvialnega izvora in jih ne določajo le spremembe klime, ampak tudi tektonsko dviganje in/ali spremembe baznega nivoja. Kraške oblike so se razvile predvsem na ostankih fluvialnih oblik ali v skladu z razmeroma neaktivnimi fluvialnimi oblikami. Starost glavnih oblik se razteza čez zelo dolgo obdobje, verjetno v razponu 15 milijonov let. Da so se te zelo stare oblike lahko ohranile, je mogoče razložiti s svojskim geomorfološkim okoljem, ki ga ni zajela poledenitev tekom pleistocena. Primerjava razvojnih modelov večih kraških morfostruktur v Južnih Alpah pomaga razumeti razlike v njihovem geomorfološkem oblikovanju.

Ključne besede: geomorfologija krasa, tipologija krasa, Južne Alpe, Monti Berici, Italija.

\section{Abstract}

UDC: $551.44(234.3)$

\section{Ugo Sauro: The Monti Berici: A peculiar type of karst in the Southern Alps}

The Monti Berici constitute the most southerly karst morpho-unit of the Southern Alps and a peculiar type of karst. The analysis of their topography, the identification of a "morpho-stratigraphy" of the relicts of surface planation and of the different types of fluvial forms, and the recognition of the few elements of chronological significance present in this context, allow the delineation of a preliminary model of the geomorphological evolution of this mountain group. The main morphogenetical elements are of fluvial origin and have been determined, not only by the climatic changes, but also by the tectonic uplifting and/or by changes of the base level. The karst landforms have mostly evolved on the relict fluvial forms or in the context of relatively inactive fluvial forms. The age of the main forms extends over a very long time span, probably in the order of 15 millionyears. The preservation of very old forms can be explained by the peculiar geomorphological environment which was not affected by glacial erosion during the Pleistocene. The comparison of the evolution models of several karst morpho-units in the Southern Alps helps to understand the differences in their geomorphological styles.

Key words: karst geomorphology, karst typology, Southern Alps, Monti Berici, Italy. 


\section{TYPES OF KARST IN THE SOUTHERN ALPS}

The Southern Alps are ideal locations to analyse and discuss the possible types of karst. There are many criteria to define each type of karst. It is possible to classify a karst environment on the basis of the lithology (limestone, dolomite, gypsum, salt, conglomerate, etc...), on the basis of the geologic structure and of the tectonic style (tabular -, homoclinal -, folded strata -, faulted blocks-, morphostructures), on the basis of the latitude (tropical or low latitude, middle latitude, high latitude), on the basis of the altitude (low, middle and high altitude), on the basis of present day climate (tropical humid, tropical humid-dry, subtropical humid, temperate oceanic, mediterranean, etc...), or on the basis of the time span needed for its evolution (young, old).

It is also possible to define a karst type on the basis of the associations of forms resulting from both karstic and non-karstic processes like fluvial, glacial, periglacial processes, etc.. Some processes have played their most effective morphogenetic role in alternate phases following the climatic and environmental oscillations of the Quaternary.

In the Southern Alps it is possible to apply many of the criteria cited above. In particular different types of fluvial, glacial and periglacial karst may be recognized. The literature deals with some of these types (Mietto and Sauro, 1989, 2000, and references therein), even if only a few detailed studies dealing with karst morpho-units of the Southern Alps from this point of view are available (Lehmann, 1959; Castiglioni, 1960, 1964; Fuchs, 1969; Sauro, 1973; Bini, Meneghel and Sauro, 1998; Ferrarese, Sauro and Tonello, 1998).

Anyway, for a full understanding of a selected karst morpho-unit it is not sufficient to classify it as a specific karst type on the basis of one or of several of the criteria cited above. This may surely help to define some of the specific features of the same morpho-unit, but in most cases it is not sufficient. It is necessary to examine the interrelations between the different erosional forms and the types and ages of the deposits located on the same forms. This helps to establish a "stratigraphy" of the forms and to delineate a history of the karst relief. If we apply such a procedure to some karst morpho-units, we will be able to discern that each is unique in some of its characteristics or events as the expression of a long environmental history.

In this perspective we have chosen not to attempt a classification of the types of karst found in the Southern Alps, but to present the most southern karst morpho-units of this region that, due to its location, altitude and the age of the constituent rocks could be considered relatively young: the Monti Berici (Sauro, 2002). An understanding of one of the younger and less eroded morphounits could also help to understand the older karst morpho-units of the Fore-Alps and of the Dolomites.

\section{THE MONTI BERICI}

The Monti Berici are a peculiar geomorphological unit: a mountain island surrounded by the high Venetian plain and marked by a combination of fluvial and karstic forms. It forms a karst plateau to the south-east of the Monti Lessini with a surface area of less than $200 \mathrm{~km}^{2}$ and a maximum elevation of $444 \mathrm{~m}$ a.s.l. (Fig. 1, 2)

The main plateau area, only $2-4 \mathrm{~km}$ wide and about $10 \mathrm{~km}$ long, is on the east side. A southeastern, lower plateau slopes gently to the western plain. Systems of branched ridges originate 


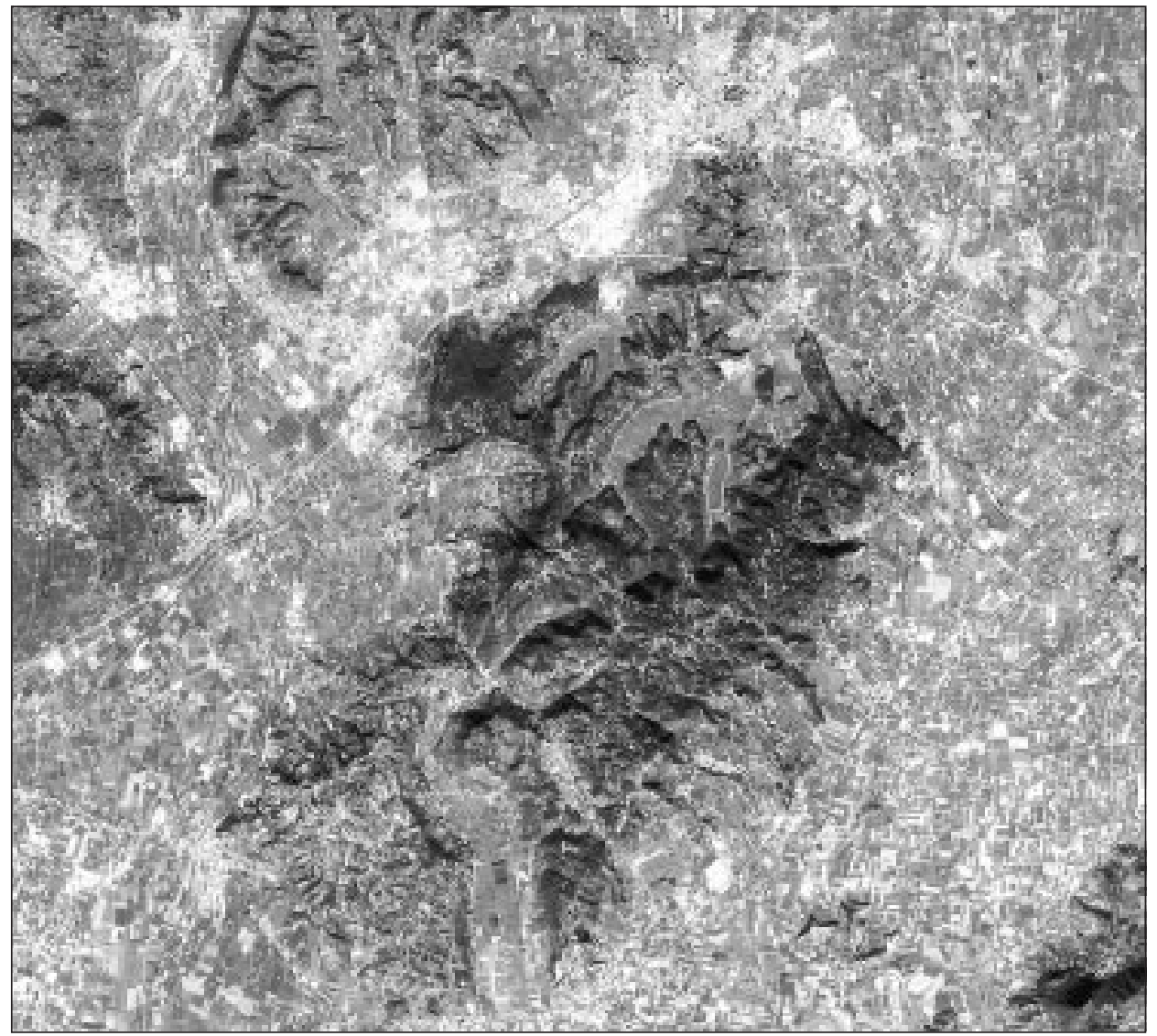

Fig. 1: The Monti Berici as seen from space. The strongly articulated relief emerges from the Venetian plain. The town of Vicenza is in the depression between the Berici and the Lessini Mountains.

from this plateau, some with the aspects of narrow plateaux or gently rounded hills. The eastern scarp of the main plateau is higher and steeper than the western.

From the morphotectonic point of view, Monti Berici is a tabular structure made up by an uplifted block consisting of a sequence of sedimentary formations mostly of Cretaceous and Paleogenic ages. The block is delimited by normal faults (Mietto, 1988a).

The asymmetry of the plateau, expressed by the much steeper south-eastern slope than that of the north-western one, is the effect of the presence on the eastern side of reef limestones less erodible than the coeval more terrigenous limestones outcropping on the western side.

Spectacular cliffs rich in weathering forms and caves cut the reef limestones (Mietto, 1988b). Some are utilised by free climbers for training.

On the plateau, beside the marine sedimentary rocks, volcanic rocks and discontinuous covers of continental deposits outcrop also. In particular, pebbles and boulders of foreign rocks are 


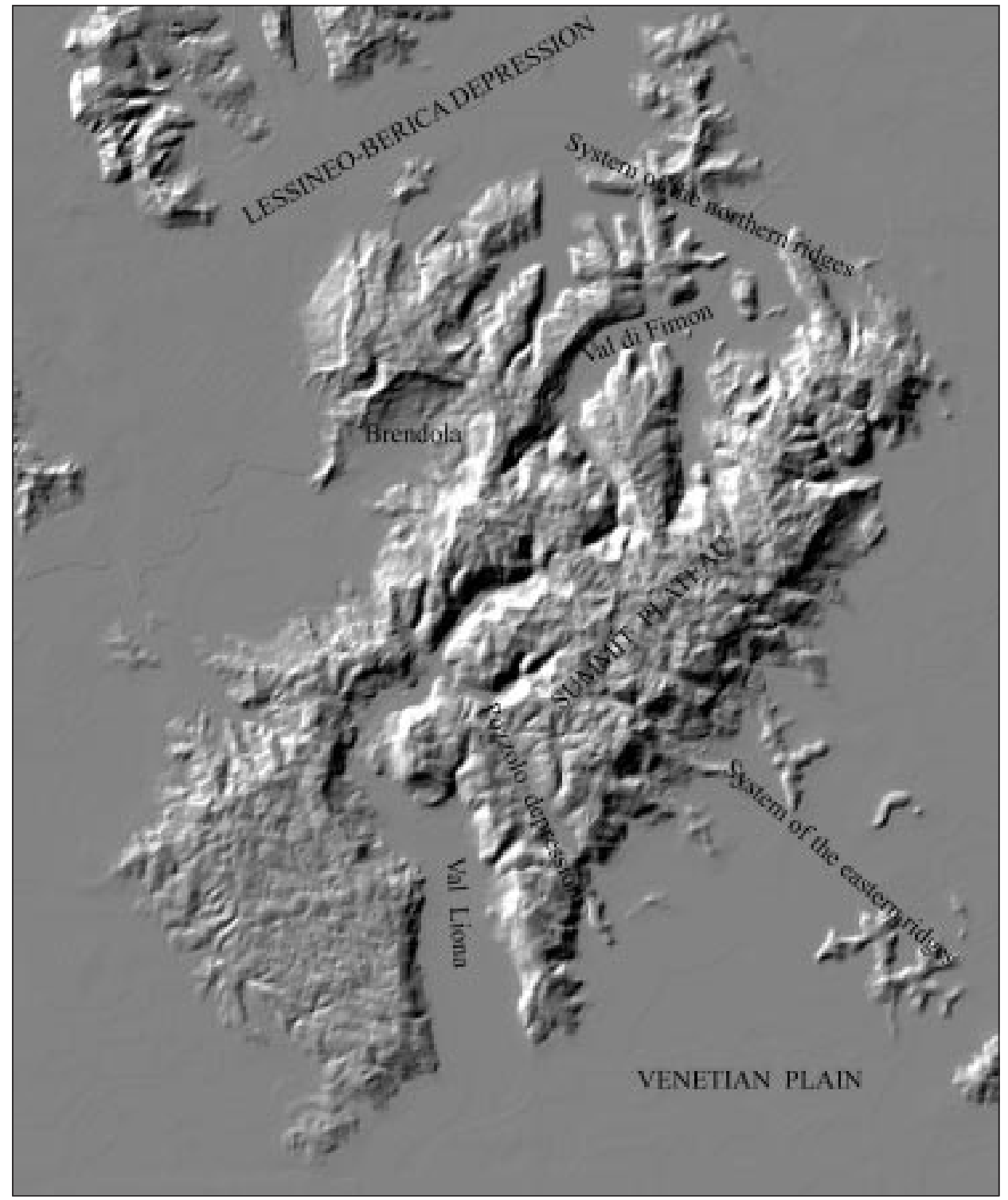

Fig. 2: Digital elevation model of the Monti Berici.

widespread. Former authors considered them as relicts of old glacial deposits (Da Schio et al., 1947; Dal Piaz, 1947).

The landforms of the Monti Berici are both of karst and fluviokarstic type. Some plateau zones are typical doline areas; others show assemblages of dry valleys, uvalas and dolines; pocked 
and canyon-like valleys are entrenched in the outer belt of the plateau. At the heads of the pocked valleys springs feed small streams utilised in the past to feed chains of mills.

A peculiar feature inside the main plateau is the depression of Pozzolo, a wide trench cutting the plateau with a NW-SE direction and hanging on both the SE and NW ends. It is the relict segment of an antecedent valley crossing the relief and cut by a river during the first uplifting phases of this morpho-unit.

\section{THE PUZZLE OF THE GEOMORPHOLOGICAL EVOLUTION OF THE MONTI BERICI}

The reconstruction of the geomorphological evolution of the Monti Berici is a fascinating puzzle, which may be partly solved on the basis of the available data. The significant points of some chronological elements are supplied by the literature and in particular by Dal Piaz (1947), Albertini (1952), Bartolomei (1958), Giulini, Piccoli \& Sbicego (1981), Mietto \& Sauro (1989, 2000), Masini, Sala \& Vorlicek (1995), Dal Molin, Mietto \& Sauro (2000).

If we organise the data in a chronological sequence we may presume that:

- the speleogenesis of some cavities inside the Grotta della Guerra Cave System, exhumed by volcanic fillings, is the consequence of the circulation of hydrothermal solutions, induced by the volcanic activity of the Paleogene or lower Neogene; after their formation the voids have been filled by magma (Dal Molin et al., 2000; Sauro 2001);

- sediments containing pollens and vegetal remains of an undefined age, between late Miocene and Pliocene, are trapped inside the Pozzolo depression (Giulini et al., 1981) and the S. Rocco doline (Bartolomei, 1958), expression of the pre-existence of these erosional forms;

- in some shafts filled by clastic sediments animal bones attributed to the the early lower Pleistocene have been discovered (Masini, Sala \& Vorlicek, 1995); these forms are further evidence of an old karstification of the massif;

- exotic pebbles spread on the plateau, consist mostly of quarzite but also of diverse magmatic and metamorphic rocks; even if these pebbles have been described as till deposits (Da Schio et al., 1947; Dal Piaz, 1947), there is no evidence of glacial morphogenesis; on the basis of the areal distribution and of the geomorphological context they may be considered the relicts of very old fluvial deposits laid down by a river when the plateau surface was at the level of the surrounding plain (Castiglioni et al., 1988; Mietto \& Sauro, 1989, 2000);

- the burying of the relief of the Monti Berici by the alluvial deposits of the plain has been interpreted by some former authors as a consequence of tectonic subsidence (Albertini, 1952); after more recent data, the evolution of an erosional relief also at elevations considerably below the present day sea level occurred during the Messinian (late Miocene) when the Mediterranean basin becomes closed and so the base level lowered considerably;

- the digs in the caves of the Monti Berici have unearthed bones of big mammals and archeological remains pertaining mostly to the Upper Pleistocene; during this period important weathering processes strongly modified the entrance parts of the caves (Bartolomei, 1984; Cremaschi, 1984; Broglio, 1988).

Only by putting these data in the geomorphological context of the morpho-unit is it possible to get a preliminary model of the relief history. 


\section{TOWARDS A “MORPHO-STRATIGRAPHY” OF THE MONTI BERICI} forms.

In a relief model of the Monti Berici it is possible to recognize both areal and linear erosional

Among the areal forms it is possible to distinguish:

- the surface of the summit plateau, extending between 400 and $250 \mathrm{~m}$ a.s.l. (plus the surface of the south-western plateau which extends at a lower altitude), that may be interpreted as a planation surface only partly controlled by the bedding of the sedimentary formations: it is a sub-structural planation surface (Castiglioni et al., 1988);

- relicts of a planation surface corresponding to the tops of the northern ridges (Valmarana, Arcugnano-M. Berico, M. Bisortole and Villa Brunello); this paleosurface may be located between 150 e $180 \mathrm{~m}$ a.s.l.;

- relicts of a planation surface corresponding to the tops of some eastern ridges extending from the foots of the large eastern scarp (ridge north of Castagnero, Mossano-S. Pancrazio ridge, isolated hilly groups of Monticello and Albettone); the elevation range of this surface is 70-100 m (Fig. 3).

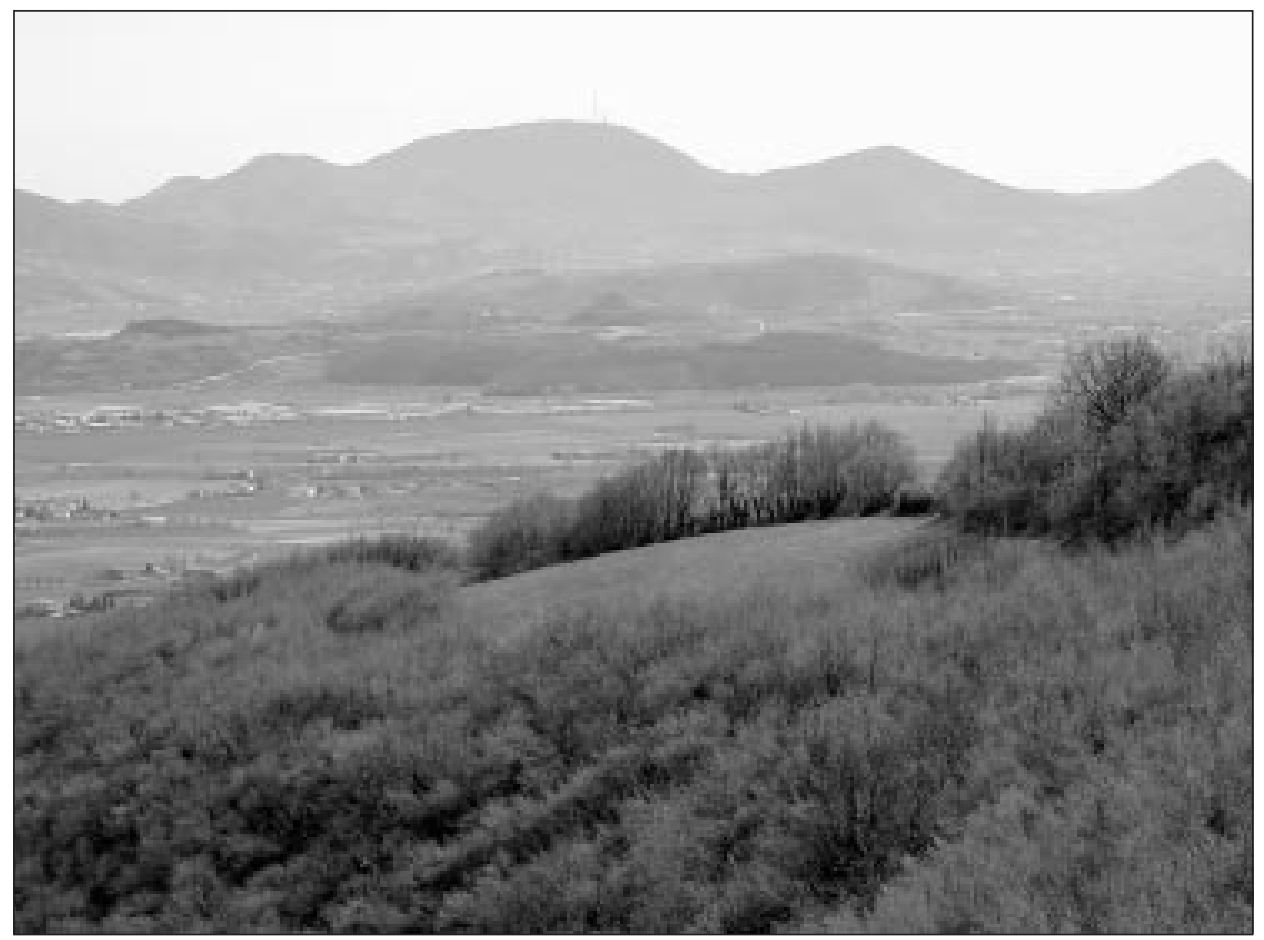

Fig. 3: The low plateau of Albettone in the central part of the photo is one of the relicts of the "eastern ridges planation surface" arising in the plain between the Berici and Euganei. The evolution of this surface is perhaps linked to the transgression of the Mediterranean sea during the Pliocene. 
From the "morpho-stratigraphical" point of view the oldest surface is the highest and the youngest is the lowest.

Among the forms which originated from linear erosion it is possible to distinguish:

- the segment of the antecedent valley of Pozzolo, entrenched in the plateau and hanging more than $100 \mathrm{~m}$ above the level of the plain; its bottom is between 150 and $170 \mathrm{~m}$ a.s.l. (Fig. 4);

- many canyon-like valleys converging in wide, flat bottom and fluvial sedimentation valleys open towards the surrounding plain.

If we consider that the development of some of the deeper valleys probably started from old antecedent segments, it is possible to recognize an old antecedent meander with a bending radius of about 1-1,5 km, corresponding to the Pozzolo depression and the Val Liona. A lateral indentation of another meander with a bending radius of about $1,2 \mathrm{~km}$ is also recognizable west of Brendola.

The "stratigraphy" of these different categories of linear erosion landforms is: 1) relicts of antecedents meanders of Pozzolo-Val Liona and Brendola, 2) canyon like valleys and valleys partly filled by alluvial sediments.

Putting together the areal and linear erosion forms the resulting morpho-stratigraphy from the oldest to the youngest is: 1) upper paleo-surface, 2) northern ridges paleo-surface + entrenched paleo-meanders of Pozzolo-Val Liona and Brendola), 3) canyon like valleys and alluvionated valleys, 4) eastern ridges paleo-surface.

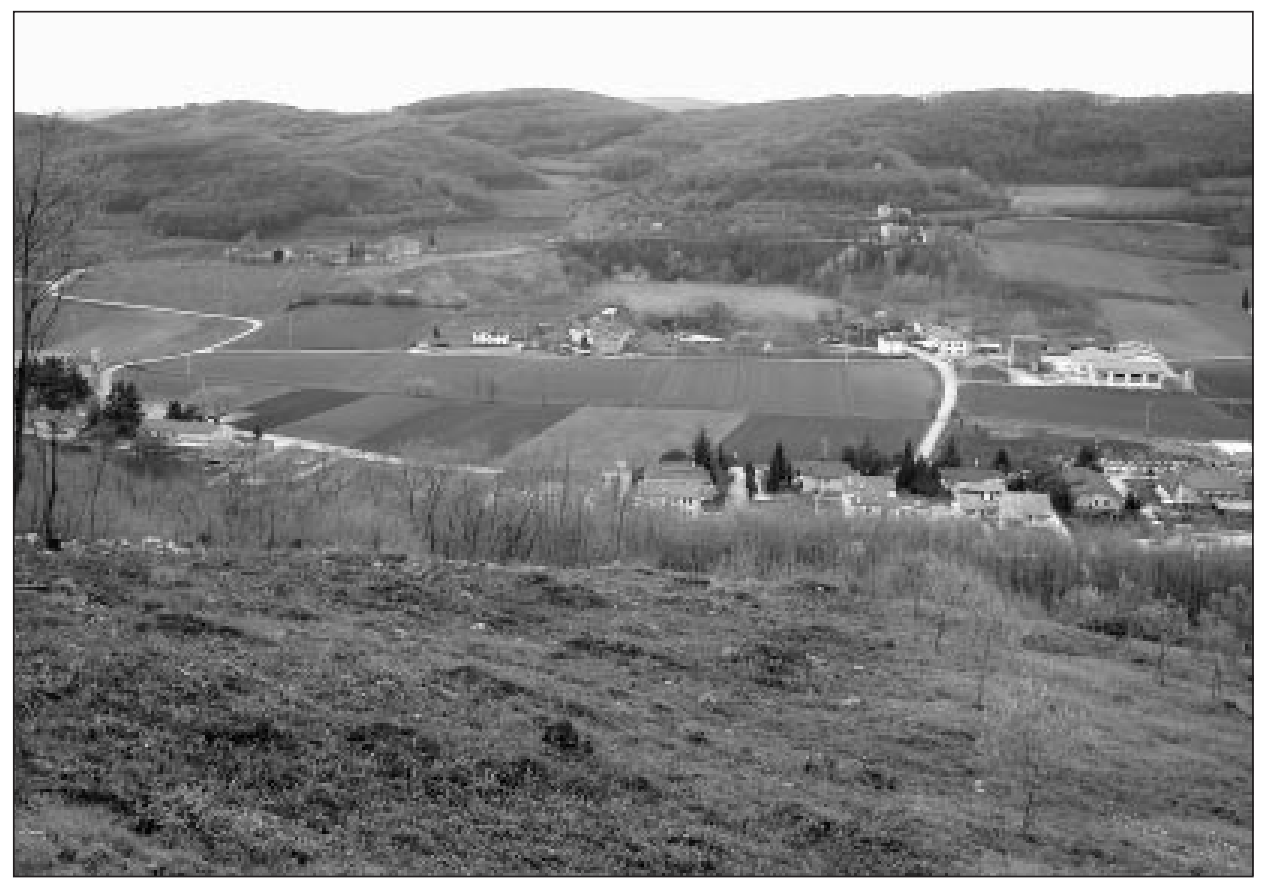

Fig. 4: View of the depression of Pozzolo: a relict valley entrenched inside the upper plateau. In the quarry the old colluvial fillings are exposed. 


\section{THE EVOLUTIVE FRAMEWORK OF THE MONTI BERICI}

By linking together the chronological elements with the related forms it is possible to delineate a preliminary model of the evolution of the Monti Berici (Fig. 5, 6).

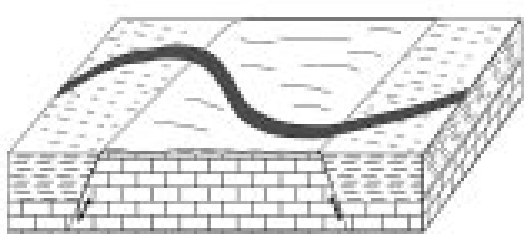

A

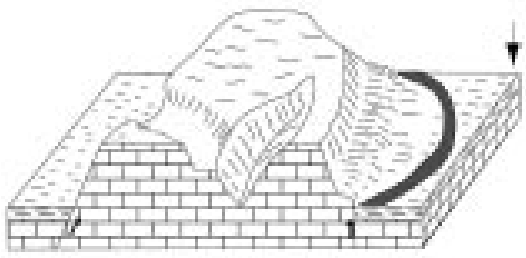

C

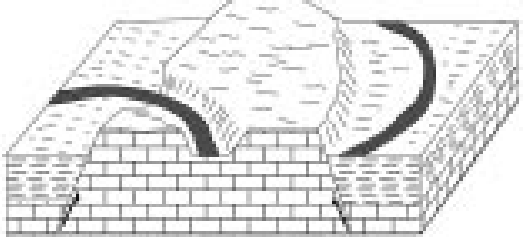

B

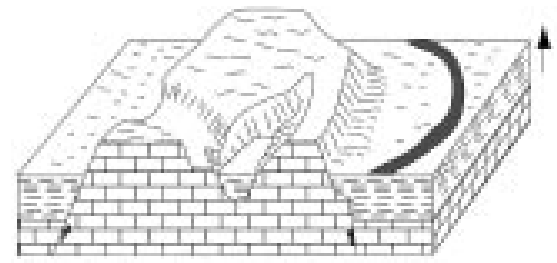

D

Fig. 5: Schematisation of the main morphogenetical phases of the Monti Berici: A) development of the early planation surface by river erosion, $B$ ) uplifting and entrenchment of the antecedent meandering valleys, C) further uplifting andlor lowering of the base level and forming of the canyon-like valleys, D) rising of the base level and partial burying of the relief by the building of the alluvial plain.

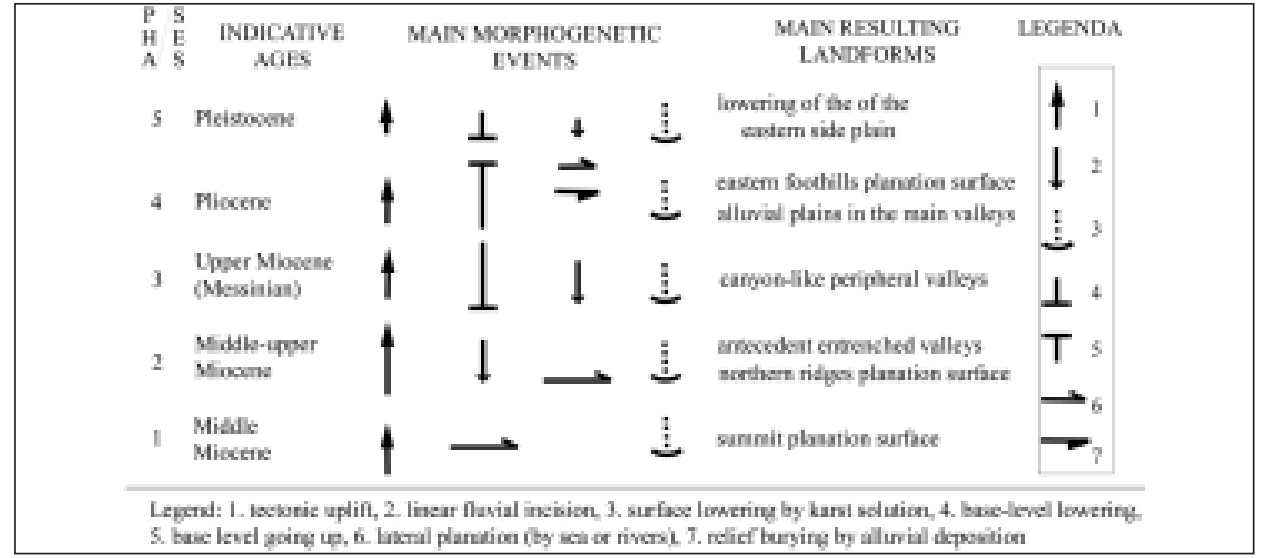

Fig. 6: Sketch of the main evolutive phases of the Monti Berici. 
The summit plateau is most likely to be an erosional surface partly controlled by the geological structure. After the marine regression, this surface has been both levelled by rivers flowing inside a fluvial plain and covered by a mantle of alluvial sediments. These sediments including pebbles made up by alpine rocks are widespread over the whole plateau and are found in a geomorphological environment which is completely lacking in any glacial erosional forms, and so can not be explained as till sediments.

After this phase of areal fluvial planation and fluvial sedimentation an uplifting episode occurred with development of a low plateau. If we consider that a large river has been able to cut its valley inside the plateau, the uplifting speed should have been moderate. So, the entrenched meanders of Pozzolo-Val Liona and Brendola developed.

The bending radius of a meander is proportional to the size of the corresponding river. Comparing the sizes of these entrenched meanders with the meanders of the present day rivers, we

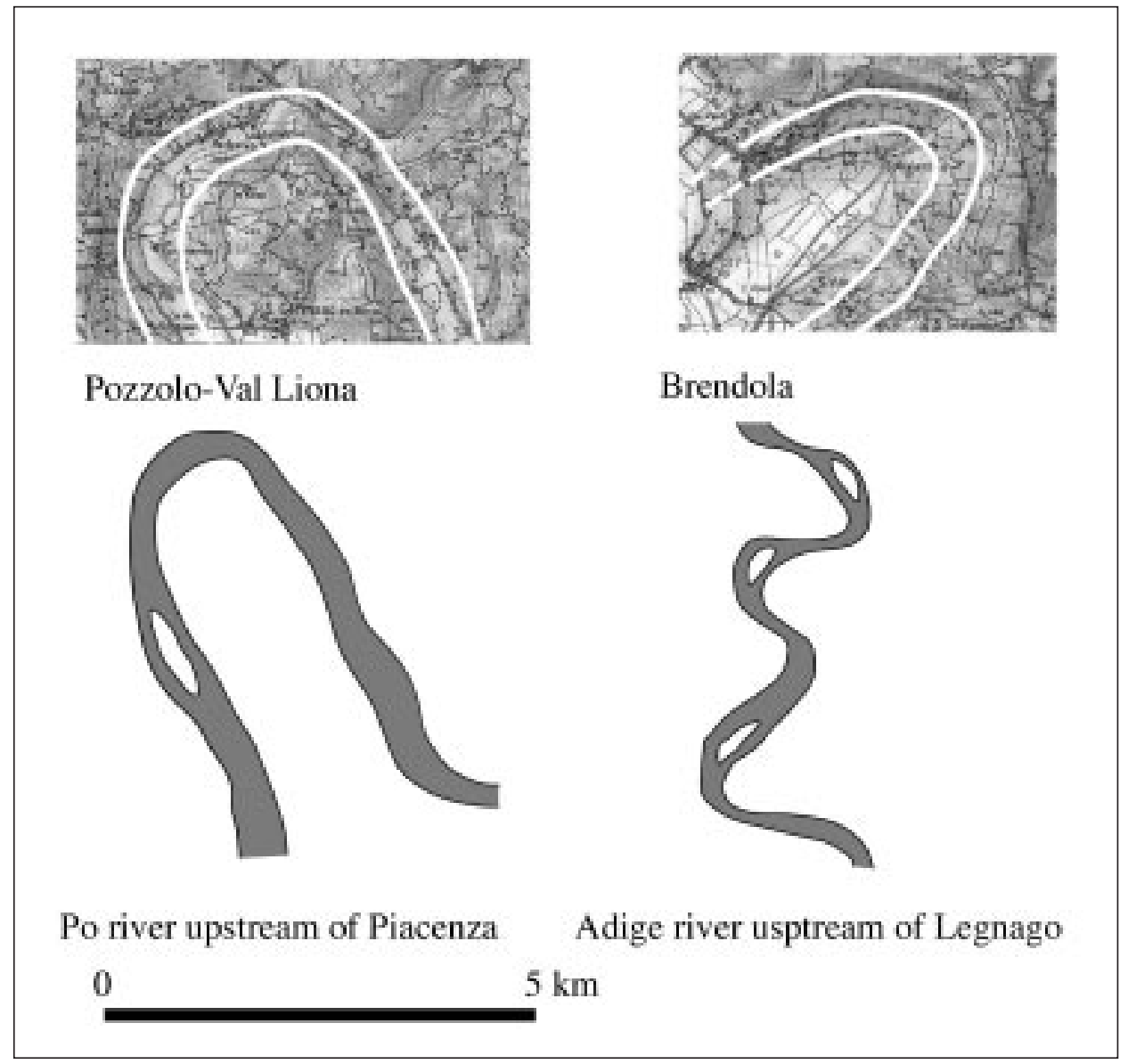

Fig. 7: The outlines of the entrenched meanders of Pozzolo-Val Liona and of Brendola compared with the present day meanders of the Po and Adige rivers. 
find that the meanders of the Po river near Piacenza are nearly of the same size (bending radius of about 1-1,2 km). So, we may assume that the river which first eroded the plateau surface and then entrenched its meanders into it was about the same size of the present day Po river in its middlelow course (Fig. 7).

In the same morphogenetical phase this river could have shaped the planation surface recognisable from the tops of the northern ridges. These tops are nearly at the same altitude interval as the bottom of the Pozzolo paleo-valley.

The successive phase is characterized by the abandonment of the Berici relief by the large river following a later uplifting phase and a lowering of the base level. It is also possible that both phenomena had acted simultaneously. An important fall of the base level took place in the late Miocene, during the Messinian stage, between 6 and 5 millions of years ago. In that period the Mediterranean sea partially dried, following the interruption of the communication with the Atlantic Ocean and so sea level lowered several hundreds of meters. In this situation the rivers were also able to deepen their valley bottoms below the present day sea level. Alongside the Valle di Fimon and the Val Liona, also the depression of Vicenza, between the Berici and the Lessini Mountains, could represent an old relict valley, entrenched in that phase. Unfortunately we have no sure data about the thickness of the filling sediments inside the outer segments of the Berici valleys.

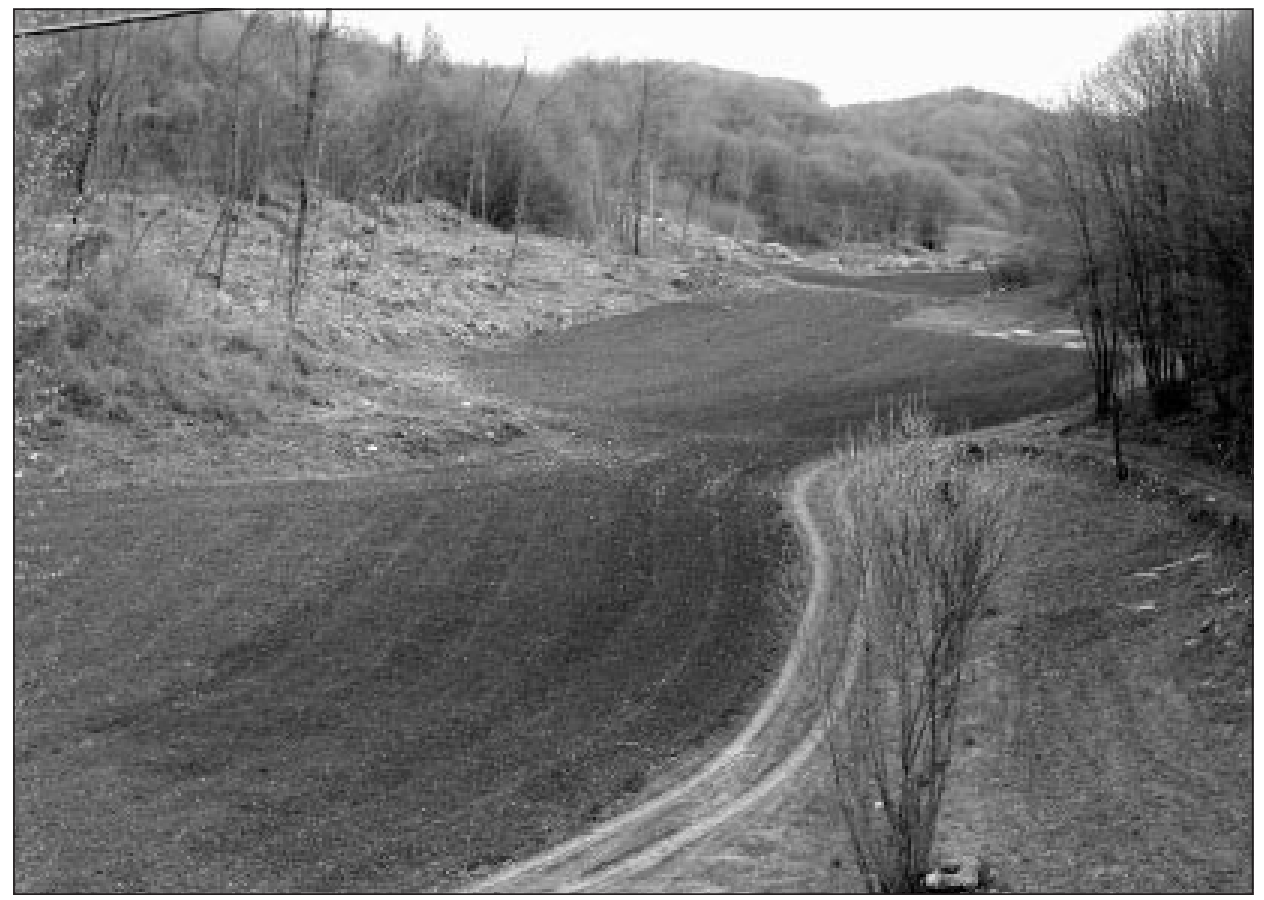

Fig. 8: An old valley of the plateau surface dried by karst morphogenesis. The early fluvial morphogenesis occurred on the fluvial sediments covering the limestone of the old planation surface. 
In the Pliocene the communication between the Mediterranean and the Atlantic was re-established and most of the Po plain was submerged. The planation surface of the eastern ridges could perhaps represent a wide marine terrace linked with the level of the Pliocene sea.

The Castagnero meander entrenched in this paleo-surface could have developed following a new relative lowering of the base level in the late Pliocene or lower Pleistocene.

After their developments, the relict forms, like the plateau surface and the entrenched meanders, have been modified by different weathering processes. In particular the plateau surface has been firstly affected by local fluvial morphogenesis, with the development of a network of small valleys, and later by karst morphogenesis with the evolution of uvalas, dolines, etc., in correspondence with the fluvial segments (Fig. 8).

The bottom of the Pozzolo relict valley was lowered by the karst solution operated by the water hosted in the sediments trapped in the depression. This segment is now evolving as a large uvala which widens more rapidly in the middle sector than at the extremities. The strike and dip of the trapped sediments has changed as a consequence of the differential lowering of the rocky bottom. It is highly probable that several tens of meters of rock has also been eroded by the karst denudation on the main plateau surface.

\section{PARTICULAR MORPHOGENETIC ENVIRONMENTS}

Between the morphogenetical environments that have marked the evolution of the Monti Berici some are worthy of mention.

Definitely, the most typical environment of this history is the fluvial one. The main forms have been originated by a large river. The karst morphogenesis has been aided by the pre-existence of an old paleokarstic subterranean network originated by a hydrothermal circulation during the last volcanic phases of the Paleogene. Also the presence of hanging aquifers inside the alluvial deposits of the pla-

Fig. 9: The pocket valley called Calto on the west side of the Pozzolo depression originated from the creek formed by the springs fed by the aquifer hosted in the sediments of the Pozzolo basin. In the past the water was utilised by some mills.

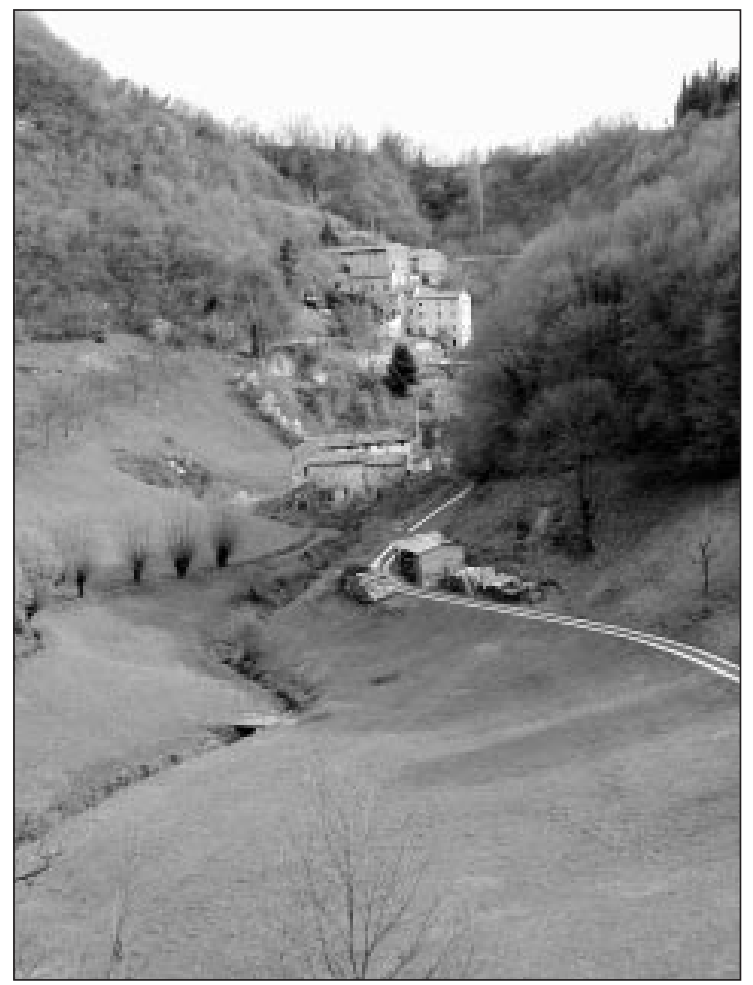


teau has aided the speleogenesis of the underlying carbonate formations.

Cover dolines have developed on the alluvial mantle. The head springs of the pocked valleys, fed by the hanging aquifers, have represented the starting points of the canyon-like valley development. The best example of a pocked valley is the Calto Valley, on the western side of the Pozzolo depression, fed by the aquifer hosted in the sediments trapped inside the same basin (Fig. 9).

Also arid and semi-arid geomorphological environments are documented: a) by quartzitic sands sorted by the wind and afterwards deposited inside karst depressions such as the dolina di San Rocco, and b) by sheetflood- like colluvial deposits present inside the Pozzolo depressions. The exact ages of these deposits are not yet known but a possible attribution could be to the upper Miocene, when the Mediterranean basin was partially dried.

Large amounts of rocky fragments are present in the entrance sectors of the caves, documenting phases of intense periglacial weathering during the Upper Pleistocene (Bartolomei, 1984; Broglio, 1988).

\section{AN EXTENDED HISTORY}

Normally, the fore-alpine and alpine landscape are referred to the most recent geological era of Earth history - the Quaternary, lasting from about two millions of years. In the case of the Monti Berici, if the model outlined is correct, the mosaic of the main landforms has to be related to a much longer time interval. If the marine sedimentation ceased during the lower Miocene, the emersion and the planation could have started nearly 15 million years ago and the entrenched paleo-meanders probably date from 6 million years ago, when the important lowering of the base level occurred which was determined by the "drying" of the Mediterranean. The canyon-like valleys could have begun their main deepening phase from about 6 million years ago.

If so, this geomorphological environment has behaved as a relatively conservative one given the relict forms and the modest slope of the plateau surfaces, the development of a karst hydrology and the absence of episodes of glacial erosion by both alpine tongues and local apparatus.

For these reasons the "stratified" landform generations identifiable in the Monti Berici extend for an extended time interval in comparison with the "normal" alpine relief.

Comparing these karst morpho-units with others in the Southern Alps we are able to find analogies and differences. As in the Berici, in the Montello karst which is the youngest of the region, the karst landforms are sculptured on a framework of level surfaces previously moulded by the fluvial processes following different phases of uplifting (Ferrarese, Sauro and Tonello, 1998). But in the Berici the surface karst landforms are well developed only on the plateau surface and are relatively scarce on the relicts of the lower planation surfaces. So, the surface karst morphogenesis appears to be relatively quicker in the Montello than in the Berici.

In the dolomitic plateau of Fanes, Sennes and Fosses developed on mesozoic age limestones and dolomites, the closed depression are glaciokarstic forms set in a complex framework of surfaces of glacial erosion (Bini et al. 1998). Curiously there are scattered exotic quartzite pebbles of "Augestein" type found here also, the expression of an old (late Oligocene - lower Miocene ?) burying phase by alluvial or coastal deposits of a previous karst topography developed on a planation surface of marine or fluvial origin. In this high mountain karst the traces of the earliest 
morphogenetical phases, probably occurring in a coastal or fluvial environment, are nearly completely lacking, except for these scattered sediments and the fillings of some very old caves.

But these are only some of the highlights of a long history of the Southern Alps still waiting to be discovered in much of its details. Surely the research work on the different karst morphunits and the comparison of their evolution models will bring new surprising results, bringing us a greater knowledge of the different karst types.

\section{*NOTA}

Research was carried out under the following research programs: progetto di Ricerca dell'Università di Padova (Geo-Ecosistemi Carsici); 60\% - 2001: Analisi degli ambienti, dei paesaggi, delle risorse e della morfodinamica in aree carsiche italiane e del Mediterraneo; 60\% 2002: Geosistemi e paesaggi carsici italiani e del Mediterraneo: storia, dinamica e risorse.

\section{REFERENCES}

Albertini, R. 1952 - Cenni geomorfologici sui Colli Berici. Riv. Geogr. Ital., 58/, 1-23.

Bartolomei, G., 1958: Resti di un carsismo terziario nei Colli Berici. Actes Deuxičme Congr. Int. Spéléol., Bari - Lecce - Salerno 1958, 1, 216-219.

Bartolomei, G., 1984: Evoluzione fisica e biologica dal Pliocene ai giorni nostri. In: Aspes A., (a cura di): "Il Veneto nell'Antichità - Preistoria e Protostoria", Banca Popolare di Verona, Verona, 113-136.

Bini, A., Meneghel, M., Sauro, U., 1998: Karst geomorphology of the Altopiani Ampezzani. Zeitschrift für Geomorphologie, Supplementband 109, 1-21.

Broglio, A., 1988: - Le grotte dei Colli Berici e la preistoria. In: AA.VV.: I Colli Berici, Natura e civiltà. Signum Edizioni, Padova, 40-69.

Castiglioni, G. B., 1960: Bosco del Cansiglio. In "Atlante internazionale dei fenomeni carsici, foglio II ${ }^{\circ}$. Ist. Geogr. Univ. Padova.

Castiglioni, G. B., 1964: Forme del Carsismo superficiale sull'altopiano del Cansiglio. Atti Ist. Veneto Sc. Lett. Arti, cl. Sc. Mat. Fis. Nat.; 122: 327-344.

Castiglioni, G. B., Meneghel, M., Sauro, U., 1988: Elementi per una ricostruzione dell'evoluzione morfotettonica delle Prealpi Venete. Riv. Geografia Fis. Din. Quatern. suppl. 1, 1988), $31-44$.

Cremaschi, M., 1984: I paleosuoli ed i depositi atriali delle cavità carsiche e dei ripari. In: Aspes, A. (a cura di): "Il Veneto nell'Antichità - Preistoria e Protostoria", Banca Popolare di Verona, Verona, 101-112.

Da Schio, A., Trevisiol, Perin, G., 1947: Scienza e poesia sui Berici. C.A.I. Vicenza, 278 pp.

Dal Piaz, G., 1947: Sui depositi morenici prewurmiani dei Colli Berici e loro provenienza. Acta Pont. Acad. Sc., 1946, 339-354.

Dal Molin, L., Mietto, P., Sauro, U., 2000: Considerazioni sul paleocarsismo terziario dei Monti Berici: la Grotta della Guerra a Lumignano (Longare - Vicenza). Natura Vicentina 4, 33-48.

Ferrarese, F., Sauro, U., Tonello, C., 1998: The Montello plateau: karst evolution of an alpine neotectonic mophostructure. Zeitschrift für Geomorphologie, Supplementband 109, 41-62. 
Fuchs, F., 1969: Studien zur Karst- und Glazialmorphologie in der Monte Cavallo Gruppe Venezianische Voralpen. Frankfurter Geogr. Hefte, 47, 114 pp.

Giulini, P., Piccoli, G., Sbicego S., 1981: Osservazioni preliminari su resti vegetali fossili provenienti da una cava di sabbia dei Colli Berici (Vicenza). Studi Trentini di Sc. Nat., 58, Acta Biologica, 271-275.

Lehmann, H., 1959: Studien über Poljen in den venezianischen Voralpen und im Hochapennin. Erdkunde 13: 258-289.

Masini, F., Sala, B., Vorlicek, P. A., 1995: Late Villafranchian Mammals From a karst Fissure at Alonte (Berici Hills, Vicenza, Northern Italy). Il Quaternario - Italian Journal of Quaternary Sciences, 8/2, 443-448.

Mietto, P., Sauro, U., 2000: Le Grotte del Veneto: paesaggi carsici e grotte del Veneto. Regione del Veneto - La Grafica Editrice (Vago di Lavagno, Verona), seconda edizione, 480 pp.

Mietto, P., 1988a: Aspetti geologici dei Monti Berici. In: AA.VV. - I Colli Berici, Natura e civiltà. Signum Edizioni, Padova, 12-23.

Mietto, P., 1988b: Carsismo e speleologia nei Monti Berici. In: AA.VV. - I Colli Berici, Natura e civiltà Signum Edizioni, Padova, 226-241.

Sauro, U., 1973: Il Paesaggio degli alti Lessini. Studio geomorfologico. Museo Civ. di St. Nat. di Verona, Mem. f. s. 6, 161 pp.

Sauro, U., 2001: Aspects of contact karst in the Venetian Fore-Alps. Acta Carsologica, 30, 2, 89-102.

Sauro, U., 2002: I Monti Berici. aspetti geomorfologici. In Dal Lago A. \& Mietto P. eds: I Monti Berici, v. 1. Museo Civico di Vicenza, in print.

\section{HRIBOVJE MONTI BERICI: SVOJSKI TIP KRASA V JUŽNIH ALPAH}

\section{Povzetek}

Običajno se predalspki in alpski relief povezuje $\mathrm{z}$ najmlajšo geološko dobo $\mathrm{v}$ zemeljski zgodovini, s kvartarjem, ki je trajal okoli dva milijona let. V primeru hribovja Monti Berici, če opisani model drži, pa moramo mozaik glavnih površinskih oblik povezovati z veliko daljšim časovnim obdobjem. V kolikor se je morska sedimentacija končala v spodnjem miocenu, je ozemlje postalo kopno in se je pričelo uravnavanje skoraj pred 15 milijoni leti. Vrezani paleomeandri so verjetno izpred 6 milijonov let, ko se je bazni nivo pomembno znižal zaradi »sušenja« Sredozemlja. Glavna faza vrezovanja sotesk se je lahko pričela pred 6 milijoni let.

Če to drži, lahko to geomorfološko okolje štejemo za tako, v katerem so se oblike dobro ohranjale, če upoštevamo reliktne oblike in rahel naklon površja planote, razvoj kraške hidrologije in odsotnost ledeniške erozije, tako s strani alpskih ledenikov ali ledenikov lokalnega izvora.

Zaradi teh razlogov se »slojevite« površinske oblike, ki jih opažamo v hribovju Monti Berici, raztezajo preko večjega časovnega obdobja, kot pa je to v primeru »normalnega« alpskega reliefa.

Če primerjamo te morfološke enote z drugimi v Južnih Alpah, lahko ugotovimo tako enakosti kot rudi razlike. Tako kot v hribovju Berici, so tudi v krasu Montella, ki je najmlajši v tej okolici, kraške oblike vrezane $\mathrm{v}$ uravnano površje, izoblikovano s pomočjo fluvialnih procesov $\mathrm{v}$ teku različnih faz dvigovanja (Ferrarese et al., 1998). Toda v hribovju Berici so kraške oblike dobro 
razvite le na planoti in so razmeroma redke na ostankih nižjih uravnav. To kaže, da je bila površinska kraška morfogeneza v Montellu hitrejša kot pa v hribovju Berici.

Na dolomitnih planotah Fanes, Sennes in Fosses, razvitih v mezozojskih apnencih in dolomitih, so zaprte depresije glaciokraške oblike v sklopu ledeniško preoblikovanih površij (Bini et al., 1998). Nenavadno je, da po njih leže posamezni eksotični kvarcitni prodniki iz »Augestein-a«, odraz starega (zgornji oligocen - spodnji miocen?) zasipa predhodnega kraškega površja, nastalega na morski ali rečni uravnavi, z aluvijalnimi ali obalnimi odkladninami. V tem visokogorskem krasu sledi starejših morfogenetskih faz, najbrž v obalnem ali rečnem okolju, takorekoč popolnoma manjkajo, razen redkih sedimentov ali zapolnitev nekaj zelo starih jam.

Toda to je samo nekaj pogledov na dolgo zgodovino Južnih Alp, ki jo bo treba v podrobnostih šele odkriti. Raziskovanje različnih kraških morfoloških enot in medsebojna primerjava njihovega razvoja skriva presenetljive izsledke, ki bi pripomogli k boljšemu poznavanju raznih tipov krasa. 